パンコムギとデュラムコムギの正逆種間交雑によって相互に遺伝子を取り込んだ 優良系統の育成

吉田 久 ${ }^{1)}$ ・ 乙部 (桐㴊) 千雅子 2) ・藤田由美子 2) ・柳沢貴司 2) ・長嶺 敬 ${ }^{3)}$

1) 荻城県阿見町， $=300-0312$

2) 農研機構・次世代作物開発研究センター, 茨城県つくば市，干 305-8518

3) 農研機構・中央農業研究センタ一北陸研究拠点, 新潟県上越市, 干 $943-0193$

\title{
Breeding of promising lines with favorable genes by interspecific hybridization between bread wheat and durum wheat
}

Hisashi Yoshida ${ }^{1)}$, Chikako Kiribuchi-Otobe ${ }^{2)}$, Yumiko Fujita ${ }^{2)}$, Takashi Yanagisawa ${ }^{2)}$ and Takashi Nagamine ${ }^{3)}$

1) Home, Ami, Ibaraki 300-0312, Japan

2) Institute of Crop Science, NARO, Tsukuba, Ibaraki 305-8518, Japan

3) Central Region Agricultural Research Center, NARO, Jyouetsu, Niigata 943-0193, Japan

キーワード

種間雑種，パンコムギ，デュラムコムギ，穂発芽抵抗性，赤さび病抵抗性，遺伝資源

\section{緒 言}

四倍体のデュラムコムギ（Triticum durum Desf.）は， 赤さび病抵抗性を示すものが多いが, 晚生で地中海沿岸 諸国やカナダなどの乾燥地帯で栽培されてきたため穂発 芽性が極易である。収穫期が梅雨に遭遇する日本では, これまで栽培できず, パスタやマカロニの原料として, カナダや米国から年間 20 万トン余が輸入されてきた.

一方，六倍体の日本のパンコムギ（Triticum aestivum L.）は，穗発芽抵抗性，早生性に関して，はるかに優孔 ているが，赤さび病抵抗性等の優良遺伝子を広く他の種 属に求めることが望李机ている.

そこで，デュラムコムギとパンコムギにそれぞれ存在 する優良遺伝子の相互利用を図ることを育種目標に種間 雑種による系統育成を実施した。

四倍体コムギと六倍体コムギの種間交雑は可能である が，雑種作出の成否はきわめて不安定であることが明ら かにされている。京都大学などでコムギの種間交雑の可 能性, 五倍体コムギ雑種に拈任染色体の行動に関寸る 基礎的研究は行われてきたが（木原 1976, Kihara 1982）, 国内のコムギ育種に両種間雑種を利用した例は少ない. 最近では, デュラムコムギの穂発芽抵抗性育種にパンコ

編集委員 : 加藤鎌司

2018 年 8 月 1 日受領 2018 年 11 月 3 日受理

2018 年 11 月 28 日 J-STAGE 早期公開

Correspondence: yoshi8h@jcom.home.ne.jp
ムギの遺伝資源が有効であることを示唆する報告がある (Kato et al. 2017).

本系統育成では，収穫期の梅雨による穂発芽を避ける ことができる早生で, 穂発芽抵抗性をもつデュラムコム ギ系統の育成, 拉よび, 赤さび病に対する抵抗性を強化 し, 良質・省力・安定生産に役立つパンコムギの育成を 目標にした.

\section{材料および方法}

\section{1. 材料}

デュラムコムギには，1991 年，倉内伸幸氏（当時, チュニジア・ケフ大学）らがチュニジア国内で探索・収 集した系統のらち, 比較的早生の系統として分譲を受け た 18 系統を選定した。一方，パンコムギは，早生，穂発 芽抵抗性などを考慮して旧農業研究センター・麦育種法 研究室で系統保存されていた 5 品種を供試した。

これらの材料は, 旧農業研究センター（現農研機構・ 次世代作物開発研究センター) ・観音台圃場に, 1994 年 10 月 27 日に秋播きした。翌 1995 年 4 月下旬に交配組及 合せの品種・系統を立毛等により選定した.

デュラムコムギは，2つの立毛タイプから「I-2（ジー ンバンク登録番号 JP239067）」と「I-18（JP239068）」の 2 系統を交配親とした。な抒，「I-18」は「I-2」に比べ て, 長稈で秙質が弱い, パンコムギは, 極早生, 穂発芽 難品種の「西海 168 号（き妨いる）」, 穂発芽難品種の 「トヨホコムギ」,「伊賀筑後オレゴン」,「東山 25 号（しゅ 
表 1. 両親の特性

\begin{tabular}{|c|c|c|c|c|c|c|c|c|c|c|c|c|c|c|c|c|c|c|}
\hline \multirow{3}{*}{ 品種名·系統名 } & \multirow{3}{*}{ 播性 } & \multicolumn{7}{|c|}{1999 年調査 } & \multicolumn{9}{|c|}{2000 年調査 } & \multirow{3}{*}{$\begin{array}{l}M F T \\
\text { 遺伝 } \\
\text { 子型 }\end{array}$} \\
\hline & & \multicolumn{3}{|c|}{ 穂発芽検定 (\%) } & \multirow{2}{*}{ 赤かび粒 } & \multirow{2}{*}{ 赤さび病 } & \multirow{2}{*}{ 稃色 } & \multirow{2}{*}{ 稃毛 } & \multirow{2}{*}{$\begin{array}{l}\text { 出穂期 } \\
\text { (月.日) }\end{array}$} & \multirow{2}{*}{$\begin{array}{l}\text { 成熟期 } \\
\text { (月.日) }\end{array}$} & \multirow{2}{*}{$\begin{array}{l}\text { 稈長 } \\
(\mathrm{cm})\end{array}$} & \multirow{2}{*}{$\begin{array}{l}\text { 穂長 } \\
\text { (cm) }\end{array}$} & \multirow{2}{*}{$\begin{array}{c}1 \text { 穂粒重 } \\
(\mathrm{g})\end{array}$} & \multirow{2}{*}{$\begin{array}{c}1 \text { 粒重 } \\
(\mathrm{mg})\end{array}$} & \multirow{2}{*}{$\begin{array}{c}1 \text { 穂 } \\
\text { 小穂数 }\end{array}$} & \multirow{2}{*}{$\begin{array}{l}1 \text { 穂 } \\
\text { 粒数 }\end{array}$} & \multirow{2}{*}{ 穂数 } & \\
\hline & & $16^{\circ} \mathrm{C}$ & $22^{\circ} \mathrm{C}$ & 判定 & & & & & & & & & & & & & & \\
\hline 農林 61 号 & II & 3.4 & 1.5 & 極難 & 0 & 中 & 褐 & 無 & 4.27 & 6.14 & 80 & 10.4 & 2.66 & 43.6 & 20 & 61 & 多 & Zen \\
\hline 伊賀筑後オレゴン & II & 4.5 & 1.8 & 極難 & 0 & 中 & 褐 & 無 & 4.30 & 6.15 & 84 & 12.3 & 2.83 & 44.9 & 21 & 63 & 多 & Zen \\
\hline トヨホコムギ & $\mathrm{II} \sim$ III & 8.2 & 1.9 & 難 & 0 & 無 & 褐 & 無 & 4.27 & 6.13 & 72 & 9.5 & 2.68 & 40.0 & 17 & 67 & 多 & Zen \\
\hline T. durum $\mathrm{I}-2$ & II & 17.5 & 16.5 & 中 & 21 & $\begin{array}{l}\text { 無 } \\
\end{array}$ & 白 & 有 & 4.27 & 6.15 & 68 & 8.9 & 1.44 & 37.9 & 14 & 38 & 多 & $\mathrm{CS}$ \\
\hline T. durum I-18 & IV & 39.1 & 18.5 & 易 & 0 & 無 & 白 & 有 & 5.02 & 6.16 & 94 & 8.4 & 1.59 & 39.8 & 14 & 40 & 多 & CS \\
\hline
\end{tabular}

両親の特性は, 表 3 の各系統のそれぞれの調査年の特性データに対応するデータとして参照.

んよう)」を交配親とし，標準品種とした「農林 61 号」 を「I-18」との久交配した。な拈，ジーンバンクには， これらの品種名の種子が保存されている，両親の特性を 表 1 と示す.

\section{2. 方法}

育成経過の概要を図 1 に示す。世代養成を重ねながら, 四倍体と六倍体への収斂を図って，系統選拔をした。

特性調查の方法は以下のと初りである.

1）穂発芽検定および赤かび粒調查（1999 年）：成熟期に 穂を採取して， $-20^{\circ} \mathrm{C}$ のリーザーに保存した． 6 月下旬 に $16^{\circ} \mathrm{C}$ 打よび $22^{\circ} \mathrm{C}$ の 2 水準，湿度 $100 \%$ の条件下に 10 日間処理して, 各温度 2 穂の平均穂発芽粒率抒よび 2 水 準込久計 4 穂の平均赤かび粒数（小数点以下は切り捨 て）を調査した.

発芽粒率に対して，次の判定基準を用いた.

ペンコムギ品種

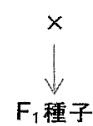

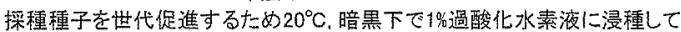
(1995.7.19)催芽处理(百足1979)し, 1996.2.8までに表2の発芽結果を得た.

\section{$F_{1}$ 個体荃成}

発莱粒はシャ一レから土を入れたポツトに移植して、緑体春化室 $\left(8^{\circ} \mathrm{C}\right.$, 12時間日長)で1ケ月春化观理(百足1979)を行い，その後, 温室 $\left(18^{\circ} \mathrm{C}\right.$, 12時間日長)でF, 個体を養成した。

$F_{2}$ 世代養成

1995年10月末までに採種できたF 2 種子は，1\%過酸化水素水処理により シャーレで催芽させた後，発芽粒を1995.11.16に煵場に移植した.

一方，11月以降採種できた $F_{2}$ 種子は，1\%過酸化水素水処理によりシヤ ーレで催芽させた後, 緑体春化室で1ケ月春化処理した。

その後, 温室 $\left(18^{\circ} \mathrm{C}, 12\right.$ 時間日長)でF 2 個体をポットで莨成した

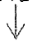

$F_{3}$ 世代糔成

1996年10月下旬，固場にF個体を播種して、4倍体と6倍体への収斂を 図るため， $F_{3}$ 世代を羕成した，施肥䒩件は，6-9-6化成肥料，7.5kg/aを 全量基肥とする標準施肥量とした.

\section{$\mathrm{F}_{4}$ 世代等成}

$F_{3}$ 世代で採種した1,016個体の粒重, 粒数調查を行い, 1穗粒数35粒 以上, 1 粒重35mg以上の充実良好な158個体を選び，20粒を1997年 10月27日に固場に $10 \mathrm{~cm}$ で点播した。

1)1998年6月の成熟期に穗摘みを行い,デュラムコムギ夕イプの㯖発军 険定を行つた。 $22^{\circ} \mathrm{C}$ で $40 \%$ 以上の穂発芽：極易， $20 \sim 40 \%$ ：易， $20 \%$ 以

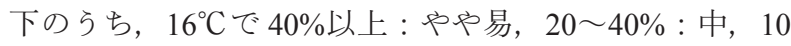
２0\%：やや難，5 $10 \%$ : 難， $5 \%$ 未満：極難.

2）赤さび病抵抗性の固場調査（1999 年）：無・微・少・ 中・多・甚の 6 階級を圃場観察により調査した.

3）穂発芽および赤かび病の圃場調査（2000 年）：株上げ したデュラムコムギ親・パンコムギ親および系統の各 10 株の主稈茎とみられる穗の穂発芽粒掞よび赤かび病粒を 調査した。

4）うどんこ病抵抗性の圃場調査（2011 年）：ジーンバン ク調査基準（現農研機構・遺伝資源センター 2018）によ る極強〜極弱の 7 階級の圑場観察により調査した.

5) 秙長・穂長調查 $(2000$ 年) : 圃場で系統内 5 個体を計 測した平均值を示した

6）粒重・粒数調查（2000 年）：株上げした各系統 10 個 体の主秙茎とみられる穂を調査した。穂数は達観により,

図 1. 育成経過の概要. 
多い系統を「多」とした.

7） MFT 遺伝子型の調査：DNeasy Plant Mini Kit （QIAGEN）を使用して，葉から抽出したDNA を用い， Nakamura et al.（2011）により開発されたCAPS マーカー (CS3A06Proseq-F3:5'-GTAGCGGGTGAAATCTGCAT-3' お’ よび CS3AProseq-R5:5'-GGGACGTACGAGGGTGTAGA-3') を使用して PCR 増幅を行った. PCR 反応は, LA Taq（タ カラバイオ株式会社)を用い, $94^{\circ} \mathrm{C} 1$ 分間行った後 $\left(94^{\circ} \mathrm{C}\right.$ 30 秒間, $60^{\circ} \mathrm{C} 1$ 分間, $72^{\circ} \mathrm{C} 1$ 分間) $\times 35$ 回, その後, $72^{\circ} \mathrm{C}$ 7 分間の条件で行った. 増幅産物は ClaI を用いて処理し た後，2\%アガロースゲルにより分離した.

\section{育成経過と結果}

育成経過を表 2 に示す。

1. 正逆交雑：着粒率は, パンコムギが雌親の場合, どの 組み合わせも $74 \%$ 以上（平均 $85 \%$ ）であったが，デュラ ムコムギが雌親の場合，「東山 25 号」の組み合わせ（I-2： $71 \%$ 乙 $-18 ： 81 \%$ ）以外では，相対的に着粒率は 68〜 43\% と低下した（データ略）が，採種は可能であった。

2. $\mathbf{F}_{1}$ 種子の催芽 : 発芽は斉一ではなくシャーレ置床後, 4 ヶ月続いた. パンコムギを雌親にした場合の発芽率は, パンコムギ品種の影響を受け，「西海 168 号」は両デュラ ムコムギの組み合わせとも75\%前後，「トヨホコムギ」 で「I-2」との交配で 56\%，「I-18」との交配で 74\%，「東 山 25 号」で両デュラムコムギの組み合わせとも $20 \%$ 前 後であった。「伊賀筑後オレゴン」では，それぞれ $18 \%$ と $65 \%, 「 \mathrm{I}-18 」$ と交配した「農林 61 号」では59\% であった。

一方，デュラムコムギが雌親の場合，発芽率は $10 \%$ 以 下となった。 パンコムギを雌親にした場合の方が有利で あるといら現象は一般に認められている（Lelley 1976）。

3. $\mathbf{F}_{1}$ 世代：パンコムギを雌親にした $\mathrm{F}_{1}$ 個体は $60 \sim 100 \%$ （平均 88\%）が稔実したが，未熟粒ではない完熟粒が採 種できた個体の割合は 35～100\% (平均 74\%) に低下した. 4. $\mathbf{F}_{2}$ 世代：パンコムギを雌親にした場合，組み合わせ により異なるが $\mathrm{F}_{2}$ 世代で 29～78\%（平均 48\%）の個体が 完熟まで展開できた。デュラムコムギが雌親の場合，稔 実した $\mathrm{F}_{2}$ 個体は養成できず, 試験の継続はできなかった. 5. $\mathbf{F}_{3}$ 世代： $F_{3}$ 世代では, 出穂期が早生から極晚性（4 月 16 日〜 月 6 日）まで広く分布したが，デュラムコムギ タイプでは，晚性になる傾向がみられた。

6. $\mathbf{F}_{4}$ 世代：圃場の特性調査では, 出穂始期の変異は, $\mathrm{F}_{3}$ 世代と同様に早生から極晚生まで広く分布した（表 2). 採種した 2,140 個体の粒重・粒数調査および穂発芽 粒・赤かび粒調査を行って, 充実良好でかつ穂発芽粒・ 赤かび粒の発生がないか, もしくは少ないパンコムギタ イプ 107 個体, デュラムコムギタイプ 74 個体, 計 181 個 体を選んだ。

な拉，1998 年 5 月から 6 月は，圃場で穂発芽，赤かび
病，らどんこ病が激発した。この 1998 年に選抜した個体 は, 穂発芽, 赤かび病, らどんこ病に対して一定の抵抗 性をもっていると期待できた。

7. $\mathbf{F}_{5}$ 世代：稃色, 稃毛の有無に注目すると, パンコム ギタイプ，デュラムコムギタイプヘ相互の両親の形質が 認められた（表 3 ).

穂発芽抵抗性を示したデュラムコムギタイプ系統で, パンコムギ品種程度に早生の系統は見いだされなかった。 前年度同様, デュラムコムギタイプの系統については, 1 系統から 1 個体を選び，穂発芽検定を行った．

選抜の結果，次年度に供試することになったデュラム コムギタイプ 40 系統の穂発芽抵抗性は, 極難 : 7 系統, 難 : 9 系統, やや難 : 15 系統, 中 : 6 系統, やや易 : 1 系 統，易：2 系統であった.

赤かび粒の発生状況は，デュラムコムギタイプの系統 で多くみられる傾向を示したが，軽微な系統もあり，パ ンコムギ親の寄与があるものと考えられた（表 3 ).

なお，1999年は赤さび病の多発年で，圃場で赤さび病 抵抗性の評価を行らことができた。

8. $\mathbf{F}_{6}$ 世代：2000 年, 圃場での特性調査および株上げし て選抜した個体の粒重・粒数調査の結果を表 3 に示す. 選抜は, 粒重・粒数調査の際, 穂発芽粒掞よび赤かび粒 の調査を併せて行った結果を総合した.

なお，2000年は，収穫直前の長雨が 6 月 9 日以降 6 日 間続き，6月9日以前に収穫できなかった系統は，穂発 芽のリスクが大きく，デュラムコムギタイプの系統につ いては，固場で穂発芽抵抗性の選抜ができた。

$\mathrm{F}_{6}$ 世代までの選抜結果では，両親の組み合わせによっ て, 選抜系統数に差異があり，パンコムギ親の「西海 168 号」や「トヨホコムギ」の組み合わせからは, 多くの系 統が選抜できた。選抜系統の早晚性は，デュラムコムギ タイプはパンコムギタイプに比べて, 晚生にシフトする 傾向となった。 また, 程長, 穂長および粒重は, 両タイ プとも両親に比べて超越分離する系統がみられた。

以上，種間交雑により，「農林 61 号」程度の成熟期で 穂発芽抵抗性をもつデュラムコムギタイプと赤さび病抵 抗性をもつパンコムギタイプの系統が選抜できた（表 3 ).

9. $\mathbf{F}_{7}$ 世代：特性調査と採種を行った 74 系統（パンコム ギタイプ 34 系統，デュラムコムギタイプ 40 系統）を遺 伝資源として登録保存した。 パンコムギタイプとデュラ ムコムギタイプの穂の形態の 1 例を図 2 に示す.

また、コムギの穂発芽を抑制する遺伝子（MFT 遺伝 子）が検出できる DNA マーカー（Nakamura et al. 2011） を使用して, デュラムコムギタイプ 29 系統と親品種系統 の遺伝子型を調査した．デュラムコムギ親系統の「I-2」 および「I-18」は，穂発芽抵抗性弱を示す CS 型 (「Chinese Spring」型), パンコムギの親 5 品種は, 穂発芽抵抗性強 を示す Zen 型（「ゼンコウジコムギ」型）であり，デュラ ムコムギタイプ 29 系統については CS 型が 15 系統, Zen 型が 14 系統であった（表 3 ）. 


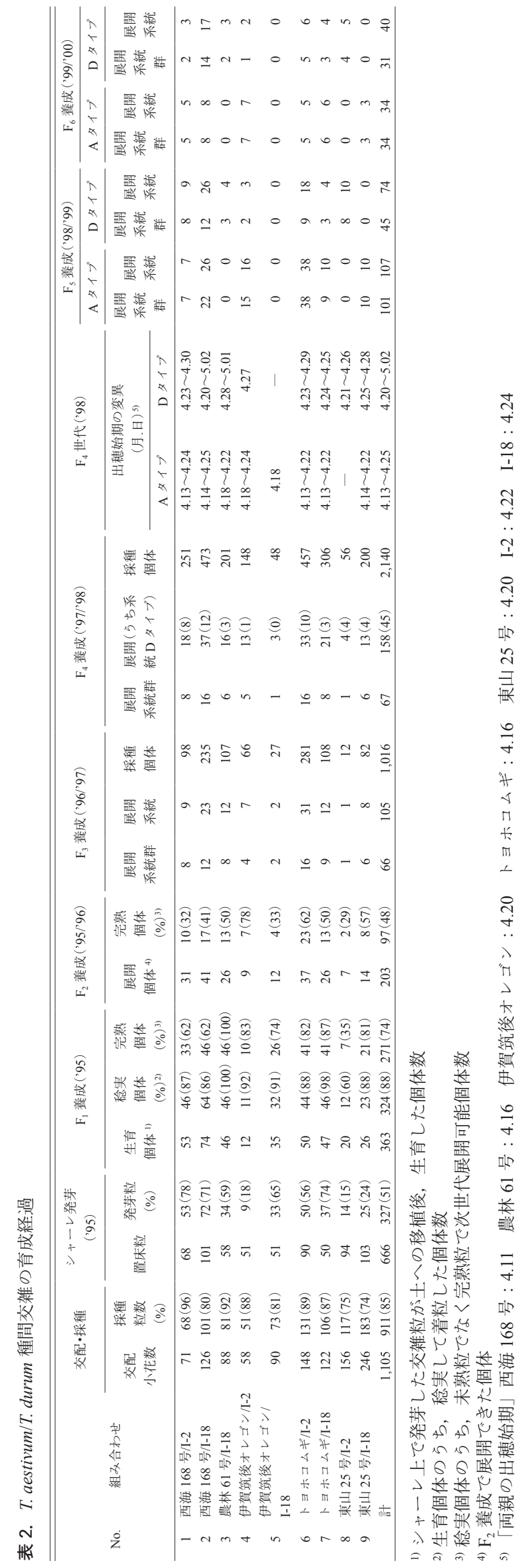




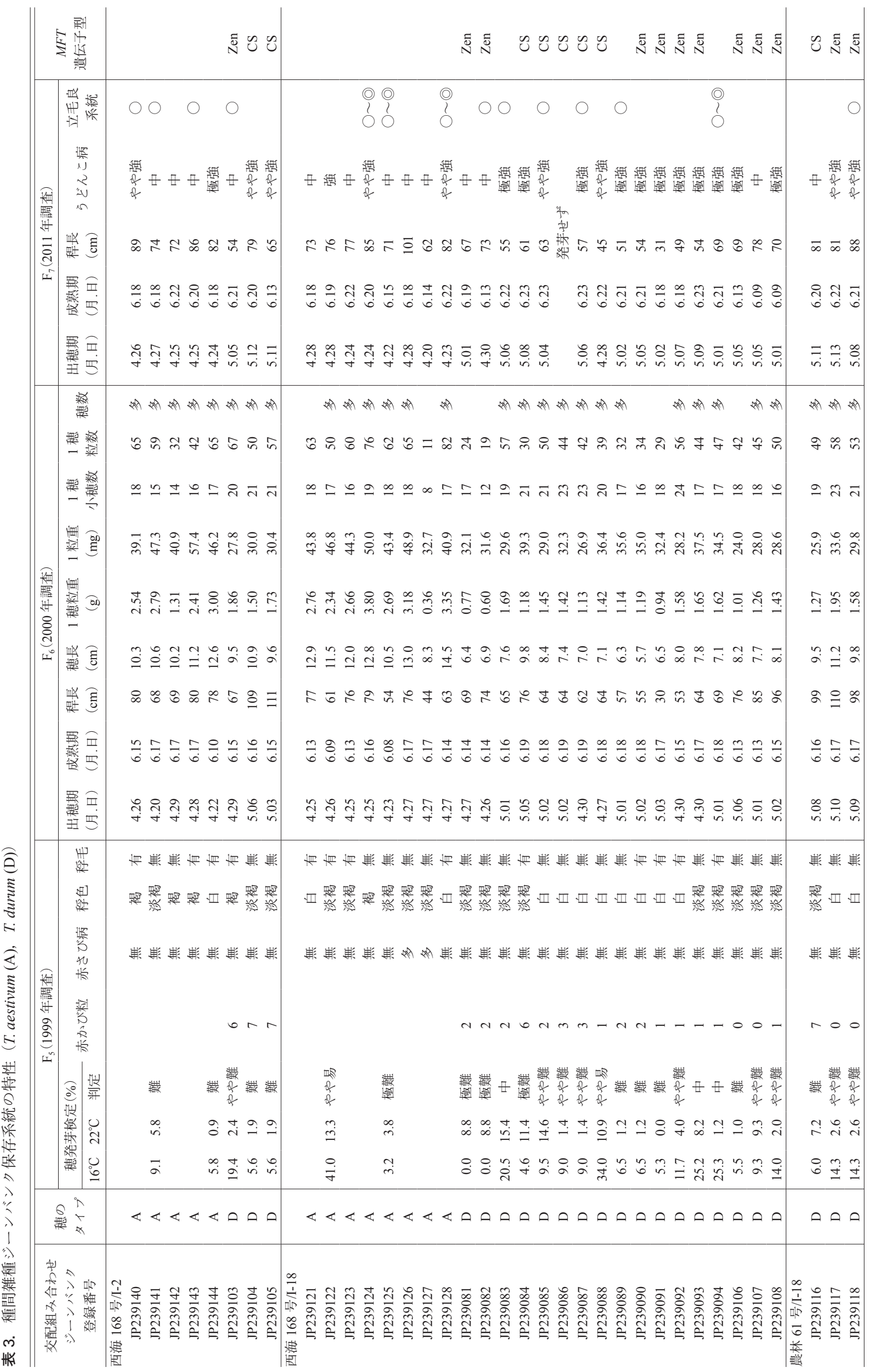




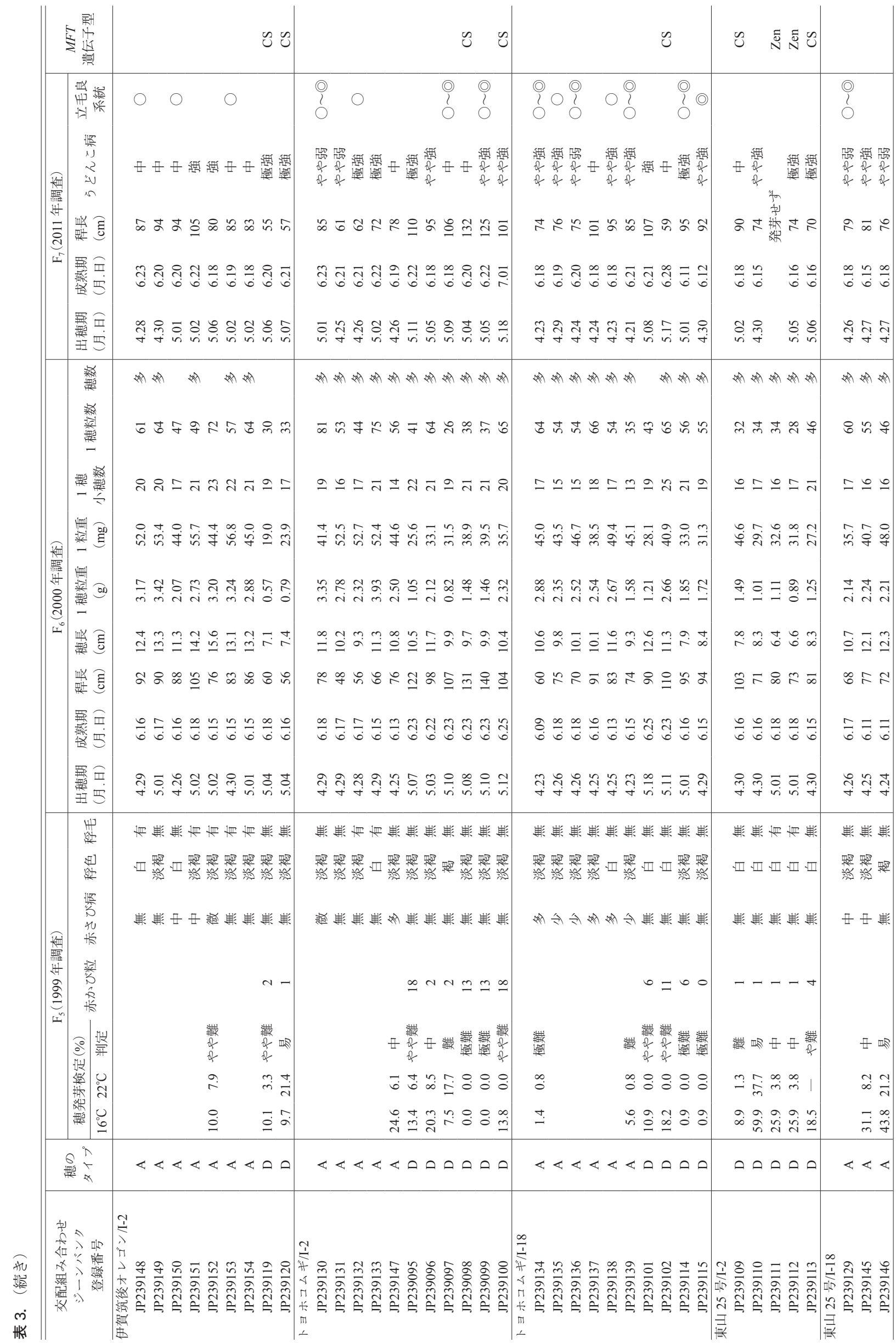




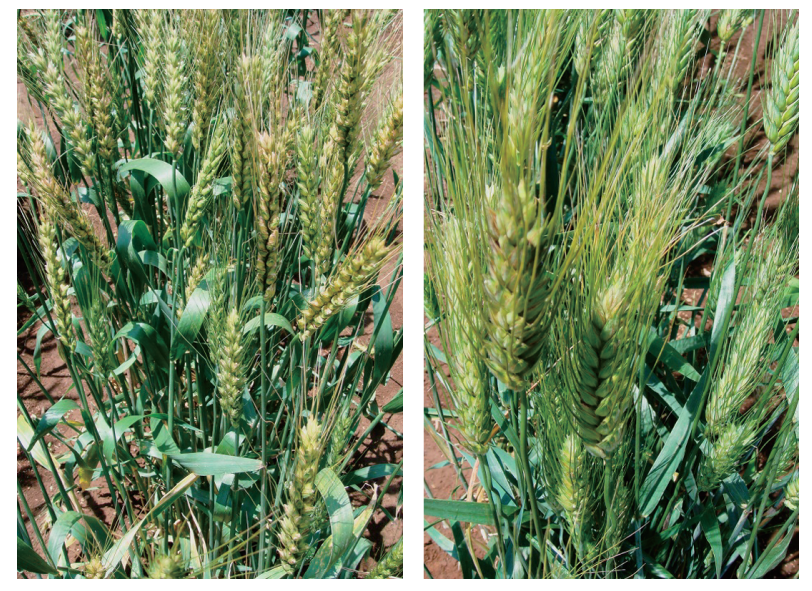

図 2. パンコムギ（A）タイプ（左）打よびデュラムコムギ（D） タイプ（右）の育成系統.

いずれも（西海 168 号/I-18） $\mathrm{F}_{7}$ 世代，JP239125 および JP239094（表 3).

\section{考察}

普通系コムギ（六倍体， $2 n=42 ）$ と二粒系コムギ（四 倍体, $2 n=28)$ との $\mathrm{F}_{1}$ 雑種は, 五倍体コムギ雑種 $(2 n$ $=5 \mathrm{x}=35,14 \mathrm{II}+7 \mathrm{I}, \mathrm{AABBD})$ となる（木原 1976, Kihara 1982). 木原によれば, $2 n=34$ から $2 n=29$ の染色体減少 群は， $\mathrm{F}_{5}$ 世代で $2 n=28$ で固定する. 一方， $2 n=36$ から $2 n=41$ の染色体増加群は, $\mathrm{F}_{5}$ 世代で $2 n=42$ となって固 定する.

本研究で選抜・育成した系統の染色体数は同定してい ない.しかし, 両種がもつ形態的特徴からパンコムギと デュラムコムギを識別することは有効であるとされてい る（舘岡 1983）。穂の形態的特徵から選抜したそれぞれ のタイプの $\mathrm{F}_{7}$ 世代では, $2 n=42$ および $2 n=28$ であると 想定された。

穂発芽は，登熟後半の気温など環境の影響を受けやす く, その生理的機構（吸水性（Yoshida et al. 1995）, 種子 休眠性（野田 1993）など）は複雑で，種子の組織が複雑 に関係している複合形質であることが知られている（桑 原 1993)。穂発芽難のパンコムギ品種「ゼンコウジコム ギ」をデュラムコムギに連続戻し交雑して作成した準同 質遺伝子系統（NILs）を解析した結果, 赤粒, MFT 遺伝 子および $Q P h s-5 A L$ を集積した NILs は最も高い穂発芽抵 抗性を示したとしている（Kato et al. 2017）.

選抜したデュラムコムギタイプの系統の中には，パン コムギ親から穂発芽抵抗性強の遺伝子型を受け継ぐ系統 が含まれることから，穂発芽抵抗性が付与された可能性 が高い. 今回用いた DNA マーカーで検出される MFT 遺 伝子は，3A 染色体に座乗して扣り，寄与率は 30\%程度と みられことから, より詳細な形質調査が望まれる.

また，デュラムコムギへの穂発芽抵抗性の獲得ととも に，早生化を目論んだが，デュラムコムギタイプの系統 は，パンコムギタイプの系統に比べて，晚生の傾向を示
した。 パンコムギはDゲノムを取り込むことによって生 理生態的に四倍体の適応しえない地帯を含めた幅広い広 域適応性を獲得したことが指摘されている（田中 1975）. 両種の早晚性と関係しているかの解明は今後の課題であ る.

日本では種間交雑育種法は，アブラナ科（皿嶋・生井 1979）で行われている.

コムギでは，百足ら $(1975,1986)$ が，染色体工学的育 種法により異種・属遺伝子の導入により赤さび病抵抗性 育種を実践し，野生二粒系コムギやチモフェビー系コム ギの抵抗性を取り込んだ「小麦中間母本農 2 号」などを 育成した例がある。

一方，日本初のデュラムコムギ品種「セトデュール」 がデュラムコムギ品種間の交配によって，2016年に育成 され，瀬戸内地方の降雨が比較的少ない地域限定として 栽培普及に移された（谷中ら 2018）。しかし，穂発芽抵 抗性や赤かび病抵抗性に改良の余地があり, 後継品種の 育成が望まれている.

本系統育成では，両種の有用遺伝子の相互利用を目的 に戋場での立毛観察からデュラムコムギタイプとパンコ ムギタイプを選抜した，実用面では，選抜・育成したデュ ラムコムギタイプが既存のデュラムコムギ並のパスタ適 性をもっているかどらかの品質評価が望まれる。 パンコ ムギ並の穂発芽抵抗性をもち，かつパス夕適性をもった 遺伝資源は，日本はもとより，穂発芽性で栽培できない 国・地域にも貢献できるであろら。また，赤さび病抵抗 性をもつ早生・大穂・短強秙のパンコムギタイプは, 交 配母材として，今後の育種事業に利用されることが期待 される。

これらの種子は, 農研機構・遺伝資源センターの農業 生物資源ジーンバンクのウェブサイトから検索でき, 試 験研究用または教育用として種子の配布を受けることが できる。

\section{謝 辞}

本研究は農水省「作物開発強化事業」（平成 $6 \sim 10$ 年 度）によって実施された。育種を進める上で旧農業研究 センター企画調整部業務科職員が圃場管理に従事した。 また，室内特性調査などについて，契約職員の協力を得 た.これらの方々に対して，謝意を表する。

\section{引用文献}

Kato, K., W. Maruyama-Funatsuki, M. Yanaka, Y. Ban and K. Takata (2017) Breed. Sci. 67: 466-471.

木原 均 (1976) 自然, 1月号: 95-103.

Kihara, H. (1982) Wheat Studies-Retrospect and Prospects-, Kodansha LTD, Tokyo, Elsevier Scientific Publishing Company, Amsterdam-Oxford-New York, 1-18, 19-51.

桑原達雄（1993）育種学最近の進歩, 第 35 集: 130-135. 
Lelley, J. (1976) Wheat breeding-Theory and Practice-, Akademiai Kiado, Budapest, 174-175.

百足幸一郎・神尾正義・細田 清（1975）育種学最近の進歩, 第 15 集: 65-74.

百足幸一郎（1979）育種学最近の進歩，第 20 集: 108-115.

百足幸一郎・細田 潔・山守 誠（1986）東北農試研報 73 号: $1-13$.

Nakamura, S., F. Abe, H. Kawahigashi, K. Nakazono, A. Tagiri, T. Matsumoto, S. Utsugi, T. Ogawa, H. Handa, H. Ishida et al. (2011) Plant Cell 23: 3215-3229.

野田和彦（1993）育種学最近の進歩, 第 35 集: 136-139.
農研機構・遺伝資源センター（2018）植物遺伝資源特性調査マ ニュアル (小麦) [http://www.gene.affrc.go.jp/manuals-plant_ characterization.php]

皿嶋正雄・生井兵治 (1979) 育種学最近の進歩, 第 20 集: 63-71. 田中正武（1975）栽培植物の起源, NHK ブックス, 81-89.

舘岡亜緒（1983）植物の種分化と分類, 養賢堂, 152-154.

谷中美貴子・高田兼則・石川直幸・船附雅子・長嶺 敬 (2018) 農研機構報告・西日本農研 18: 13-28.

Yoshida, H., A. Horigane and A.K. Horigane (1995) Proc. 7th Int. Symposium on Pre-Harvest Sprouting in Cereals, 79-85. 